\title{
USING THE OUTSOURCING SCHEME IN THE FIELD OF FORESTRY IN UKRAINE
}

\section{Використання схеми аутсорсингу в сфері лісового господарства України}

\begin{abstract}
The article analyzes the theoretical aspects of using the outsourcing scheme in the enterprise activity, identifies the ways of separating woodworking shops from the structure of state forestry enterprises and justifies the necessity of using the outsourcing scheme in the field of rendering services in forest rehabilitation and reproduction.

The purpose of the research is to develop theoretical and practical recommendations for the improvement of forest management in Ukraine through the use of outsourcing scheme in the field of forestry services and wood processing.

The object of the research is economic relations in the field of forestry in Ukraine.

The method of normative analysis is used to determine the basic norms, which are guided by the subjects of management in the field of forestry in Ukraine; abstractlogical method is used to identify contradictions in the existing system of forestry activities; axiomatic method is used to identify conflicts of interest in the activities of employees of state forest enterprises; the method of institutional comparative analysis is used to determine the main shortcomings of state regulation of entrepreneurship and to substantiate ways to eliminate them.

The separating woodworking shops from the structure of state forest enterprises will simplify the management system of these enterprises, reduce administrative costs, increase revenues from the sale of unprocessed timber and increase competition in the market of unprocessed timber.
\end{abstract}


Involving for rendering services in forest rehabilitation and reproduction third parties will create conditions for deepening the division of labor and the specialization of forestry contractors and improving the quality of services which provided, that in result will allow forestry companies to purchase these services at lower prices and higher quality. In case of establishing the requirement for the purchase of all forestry services through free-range tendering, third-party forestry service providers will be able to develop their own production without establishing corruption-related links with the management of state forest enterprises. The positive moment of postponement of the proposed measures for the state is to simplify and streamline economic relations in the forest sector, reduce the level of economic crime and increase the level of tax revenues to the state and local budgets.

\section{Анотація}

У статті досліджено теоретичні аспекти використання схеми аутсорсингу в діяльності підприємства, визначено шляхи відділення деревообробних цехів із структури державних лісогосподарських підприємств України та обгрунтовано необхідність використання у сфері надання послуг з лісовідновлення й лісорозведення схеми аутсорсингу.

Метою дослідження є розробка теоретичних положень і практичних рекомендацій з удосконалення лісогосподарської діяльності в Україні шляхом використання у сфері надання лісогосподарських послуг та деревообробки схеми аутсорсингу.

Об’єктом дослідження є господарські відносини у сфері лісового господарства України.

Метод нормативного аналізу - для визначення основних норм, якими керуються суб'єкти господарювання у сфері лісового господарства України; абстрактно-логічний метод - для виявлення суперечностей в існуючій системі лісогосподарської діяльності; аксіоматичний метод - для виявлення конфлікту інтересів у діяльності працівників державних лісогосподарських підприємств; метод інституціонально-порівняльного аналізу - для визначення основних недоліків державного регулювання підприємництва та обгрунтування шляхів їх усунення.

Відділення деревообробних цехів із структури державних лісогосподарських підприємств України дозволить спростити систему управління цими підприємствами, знизити адміністративні витрати, збільшити доходи від реалізації необробленої деревини й посилити конкуренцію на ринку.

Залучення до виконання послуг з лісовідновлення та лісорозведення сторонніх суб'єктів господарювання створить умови для поглиблення поділу праці, спеціалізації лісогосподарських підрядників і підвищення рівня якості 
надаваних послуг, внаслідок чого лісгоспи зможуть закуповувати ці послуги за нижчими цінами й вищою якістю. У випадку встановлення вимоги закупівлі усіх лісогосподарських послуг через процедури вільних торгів сторонні підприємства-надавачі лісогосподарських послуг зможуть розвивати власні виробництва без встановлення корупціогенних зв'язків з керівництвом держлісгоспів. Позитивним у запропонованих заходах для держави $€$ спрощення та упорядкування економічних відносин у лісовій сфері, зниження рівня економічної злочинності й зростання рівня податкових надходжень до державного та місцевих бюджетів.

KEYWORDS: state forestry, wood processing, forestry services, outsourcing

Ключові Слова: державне тісове господарство, деревообробка, тісогосподарські послуги, аутсорсинг

\section{Вступ}

Українська система ведення лісового господарства побудована на принципі комплексного виконання усіх лісогосподарських робіт єдиним підприємством - державним лісовим господарством. Тобто лісгосп є універсальним виконувачем цілого ряду функцій: від розведення насіння лісових культур до гасіння лісових пожеж власними силами. Однак це призводить до значного розростання таких державних лісових компаній, ускладнення процесу управління ними, збільшення постійних (адміністративних) витрат, що у свою чергу підвищує собівартість виготовлюваної продукції та знижує рентабельність капіталу цих підприємств. Це можна охарактеризувати (за Д. Нортом (Nort, 1997)) як зростання трансформаційних (виробничих) та трансакційних витрат внаслідок збільшення кількості виконуваних функцій конкретним підприємством. I в цьому випадку на ринку лісогосподарських послуг «оптимального» об’єму планування (за Р. Коузом (Kouz, 2007)) не виникне, оскільки цей ринок не є конкурентним і рішення щодо виконання кожної додаткової функції грунтуються не на економічному аналізі можливості отримання прибутку, а на політичних рішеннях бюрократії (оскільки лісгоспи є державними підприємствами і часткове їх фінансування здійснюється з державного бюджету України, то працівники лісгоспів не орієнтовані на отримання прибутку, а зацікавлені більшою мірою у збільшенні обсягу державного фінансування). Тобто виникла 
ситуація, коли за державними лісгоспами було закріплено максимальну кількість функцій, які в переважній більшості є збитковими для них.

Однак з економічної точки зору більш ефективним є розподіл праці, виокремлення структурних підрозділів із закріпленням за ними однієї або кількох сумісних між собою функцій, поглиблення їх спеціалізації, закупівлі сировини і реалізації виготовленої продукції на конкурентній основі. Поглиблення спеціалізації окремих виробничих підрозділів на виконанні окремої функції призводить, зазвичай, до зниження трансформаційних (виробничих) витрат, тобто до зниження собівартості виготовленої продукції.

Метою дослідження $є$ розробка теоретичних положень та практичних рекомендацій з удосконалення лісогосподарської діяльності в Україні шляхом використання у сфері надання лісогосподарських послуг і деревообробки схеми аутсорсингу.

Методи дослідження. Дослідження виконувалось на основі використання таких загальнонаукових методів і прийомів: абстрактнологічного методу - для виявлення суперечностей і протиріч в існуючій системі лісогосподарської діяльності; аксіоматичного методу - для виявлення та обгрунтування шляхів усунення конфлікту інтересів у діяльності працівників державних лісогосподарських підприємств; інституціонально-порівняльного аналізу - для визначення основних недоліків державного регулювання підприємництва й обгрунтування шляхів їх усунення або нівелювання; нормативного аналізу - для визначення основних норм та «правил гри», якими керуються суб'єкти господарювання у сфері ведення лісового господарства України.

\section{Теоретичні аспекти використання схеми аутсорсингу в діяльності підприємства}

На пострадянському просторі збереглися стереотипи мислення про те, що підприємство повинно організувати виробничий процес таким чином, щоб мінімально залежати від постачальників та інших контрагентів, тобто виконувати власними силами більшість виробничих операцій (маючи при цьому власні джерела ресурсів, власні підрозділи з виготовлення напівфабрикатів, інструментів тощо) і ланцюг ство- 
рення доданих вартостей був повністю в межах одного підприємства. Такий підхід був ефективним у період функціонування адміністративнопланової економіки (у часи існування СРСР), оскільки централізована система планування виробництва дуже часто давала збої (невчасно постачались ресурси, надходили суперечливі інструкції, затримувались поставки напівфабрикатів), а визначені в плані виробничі завдання необхідно було виконувати. Тому підприємства з метою мінімізації негативного впливу недосконалого планування створювались у формі самодостатніх виробничих комплексів із мінімумом зв'язків із зовнішнім середовищем.

Однак з переходом України до ринкової економіки змінились і умови господарювання. У нових реаліях метою діяльності будь-якого підприємства $є$ отримання прибутку шляхом задоволення потреб споживачів, а не виконання встановлених державним органом планових завдань. У ринковій економіці прибуток отримує той, хто виробляє затребуваний споживачем товар порівняно з конкурентами за нижчу ціну, або за ту саму ціну, але з вищою якістю. Тому й важливою стає спеціалізація виробників, яка дозволяє знижувати витрати та підвищувати якість продукції.

Тому, на думку К. Бендукідзе (Bendukidze, 2003, p. 137-138), інтегрованість $є$ неефективною моделлю. Причиною цього $є$ те, що менеджмент інтегрованих компаній не здатний впоратися з великою кількістю різноманітних бізнесів, об’єднаних в одне ціле, та високою часткою постійних витрат, що робить неможливим управління собівартістю. Одним із механізмів забезпечення ефективного (рентабельного) функціонування підприємства, на його думку, є використання схеми аутсорсингу, тобто придбання продукції і послуг, які раніше виготовлялися власними силами, у сторонніх суб'єктів господарювання на конкурентній основі.

Використанню схеми аутсорсингу передує процедура визначення ключових компетенцій, яка є безперервним процесом. Спочатку відбувається їх груба ідентифікація, тобто визначення того, що до ключових компетенцій підприємства не відноситься (визначення строго непрофільного бізнесу). Так, якщо припустити, що в інтегро- 
ваній організації є допоміжний бізнес, який істотно важливий для підрозділів, які здійснюють ключову компетенцію, але не відноситься до неї, то варто його відокремити від компаній, що забезпечують реалізацію в сфері ключового розвитку. Наступний етап - це реінжиніринг процесів у частині ключової компетенції, адаптація їх до системи ринкових відносин. У цьому випадку отримуються ще точніші ідентифікації ключової компетенції. Так повторюється безліч разів протягом багатьох років. Це - неминучість, з якою стикаються усі успішні в довгостроковому плані компанії. Точне формулювання ключових компетенцій ініціює процес дезінтеграції компетенції (Bendukidze, 2003, p. 142-144).

Ключовим чинником довгострокового успіху $є$ управління витратами за місцем їх виникнення. Модель, що припускає існування одного центру прибутку й багатьох центрів витрат, є неповноцінною і демотивуючою. Треба формувати модель так, щоб у компанії не існувало центрів витрат, а кожен підрозділ був би центром як витрат, так і прибутків. Те ж саме стосується скасування трансфертних цін після відокремлення окремих самостійних бізнесів. Правильним рішенням $€$ свобода вибору контрагентів. Замість переваг отримання послуг від колег по компанії, варто купувати послуги в колишніх колег за ринковими цінами, при цьому істотно змінюється відношення до доцільності закупівель. Менеджмент починає замислюватися над закупівлями, тому що потрібно платити гроші, а не перекладати їх з однієї кишені в іншу. Коли всі вільні у виборі постачальника послуг і товарів, це створює мотивацію для відокремленого підприємства працювати якісно. Виявляється, що не лише відбуваються зміни в обсягах продажів і собівартості, але і по-іншому мотивується діяльність малих виробництв і компаній (Bendukidze, 2003, p. 142-143).

Якщо перенести ці теоретичні напрацювання на реалії українського лісового господарства, то можна помітити, що державні лісогосподарські підприємства до цього часу виконують переважну більшість функцій, які вони мали при адміністративно-плановій економіці. Тому варто було б у їх діяльності використовувати схему аутсорсингу, провівши перед тим процедуру визначення ключових компетенцій. 


\section{Шляхи відділення деревообробних цехів із структури державних лісогосподарських підприємств України}

Необхідно зауважити, що державні лісогосподарські підприємства України у своїй назві містять ключові слова, які підтверджують, що сферою їх діяльності є лісове господарство, яке згідно Класифікації видів економічної діяльності (DK 009:2010, 2010, р. 7-8) не включає в себе деревообробку. Враховуючи також те, що відпуск деревини власним лісопереробним підрозділам держлісгоспів здійснюється на трансфертній основі (тобто деревина ним відпускається за собівартістю), доцільно було б поставити деревообробні цехи в рівні конкурентні умови з іншими (приватними) деревообробними підприємствами, виділивши ix iз структури лісгоспів із створенням окремих юридичних осіб і реалізовуючи ним продукцію на загальних умовах. Це не повинно призвести до зниження обсягів отримуваних прибутків державними лісогосподарськими підприємствами, оскільки ту величину прибутку, яку вони отримують від реалізації обробленої деревини, можна закладати в ціну реалізації необробленої деревини. Крім того, держлісгоспи у випадку проведення реорганізації отримають додаткові вигоди: знизяться постійні (адміністративні) витрати, що дозволить краще управляти собівартістю продукції, а також зростуть прибутки внаслідок скасування привілеїв та появи можливості продажу необробленої деревини за ринковими цінами.

Процедура відділення лісопереробних цехів полягає в тому, що Держлісагентство як уповноважений орган управління об’єктами державної власності (згідно Положення про Державне агентство лісових ресурсів України (Ukaz Prezydenta Ukrayiny «Pro Polozhennya pro Derzhavne ahentstvo lisovykh resursiv Ukrayiny», 2011)) своїм рішенням реорганізує держлісгоспи, розділивши їх на два незалежних державних унітарних підприємства (або ліквідує лісгосп, з подальшим створенням двох окремих підприємств): державне лісове господарство (займатиметься лише веденням лісового господарства згідно розділу 02 КВЕД (DK 009:2010, 2010)) та державне деревообробне підприємство (займатиметься деревообробкою згідно розділу 16 КВЕД (DK 009:2010, 2010)). 
У такому випадку майно збережеться в державній власності, але новостворені підприємства будуть незалежними один від одного.

Іншим можливим шляхом відділення деревообробки може стати приватизація цілісних майнових комплексів державних деревообробних цехів шляхом їх продажу на конкурсній основі згідно Закону України «Про приватизацію державного майна» (Zakon Ukrayiny «Pro pryvatyzatsiyu derzhavnoho mayna», 1992) та Закону України «Про приватизацію невеликих державних підприємств (малу приватизацію)» (Zakon Ukrayiny «Pro pryvatyzatsiyu nevelykykh derzhavnykh pidpryyemstv (malu pryvatyzatsiyu)», 1992). При проведенні приватизації варто передбачити можливість пільгового викупу державного майна членами трудових колективів підприємств, що приватизуються. Так, згідно статті 8 Закону України «Про приватизацію державного майна» члени трудового колективу підприємства, що приватизується, можуть заснувати на підставі рішення загальних зборів, у яких брало участь більше 50 відсотків працівників підприємства, господарське товариство, яке згідно статті 25 Закону України «Про приватизацію державного майна» користується пріоритетним правом на придбання цього майна за рівних запропонованих умов купівлі, а також правом на розстрочку платежу на строк не більше одного року з початковим внеском не менше 30 відсотків ціни, за яку придбано майно на аукціоні чи за конкурсом (Zakon Ukrayiny «Pro pryvatyzatsiyu derzhavnoho mayna», 1992). Тобто у випадку використання такої схеми буде збережено трудові колективи приватизованих деревообробних підприємств і продовжено їх роботу уже на конкурентних засадах і на основі приватної форми власності, а держава отримає надходження до державного бюджету коштів, одержаних від приватизації державного майна.

Варто також враховувати те, що процес відділення деревообробки від лісового господарства був затверджений в Концепції реформування та розвитку лісового господарства (Rozporyadzhennya Kabinetu Ministriv Ukrayiny «Pro skhvalennya Kontseptsiyi reformuvannya ta rozvytku lisovoho hospodarstva», 2006) та в Робочому плані (дорожній карті) на 2006 рік Державного комітету лісового господарства (Robochyy plan (dorozhnya karta) na 2006 rik, 2005), в якому зазначалось, що «з метою створення 
конкурентного середовища на ринку продукції переробки деревини, здійснити поступове відокремлення деревообробного сектору виробництва від лісогосподарської діяльності та забезпечити його функціонування на ринкових засадах». Однак цього не було здійснено, хоча у 2006 році Державний комітет лісового господарства України мав 456 деревообробних цехів, а у 2008 році їх було близько 300. Якщо в 2006 році в цьому секторі працювали приблизно 14 тис. чол., то в 2008 році - близько 8 тис. чол. Для підприємств, що залишилися, нове устаткування не купується, тобто вони продовжують експлуатувати наявне майно (Marchuk, 2008, p. 13-14). Тобто державні деревообробні цехи $є$ неконкурентоспроможними порівняно з приватними лісопереробниками навіть за умови отримання сировини не за ринковими цінами, а за собівартістю.

Такий стан справ у лісовому господарстві України можна охарактеризувати як зловживання монопольним становищем держлісгоспами наринкудеревообробки, обмеженнямконкуренціїтанедобросовісною конкуренцією. А згідно статті 42 Конституції України (Konstytutsiya Ukrayiny, 1996) «держава забезпечує захист конкуренції в підприємницькій діяльності. Не допускаються зловживання монопольним становищем на ринку, неправомірне обмеження конкуренції та недобросовісна конкуренція». Крім того, це порушує статтю 7 Закону України «Про засади внутрішньої і зовнішньої політики» (Zakon Ukrayiny «Pro zasady vnutrishn'oyi i zovnishn'oyi polityky», 2010), яка визначає, що основним чинником підвищення ефективності економіки є конкуренція, і тому важливим $є$ недопущення проявів монополізму на державному та регіональному рівнях та забезпечення рівності усіх суб'єктів права власності перед законом. Тому з метою усунення перелічених вище недоліків та порушень чинного законодавства доцільним $є$ відділення деревообробних цехів із структури державних лісогосподарських підприємств. Це усуне прояви монополізму, сприятиме посиленню конкуренції і стимулюватиме розвиток національної економіки України. 


\section{Використання схеми аутсорсингу в сфері надання послуг з лісовідновлення та лісорозведення}

Ще однією сферою діяльності лісогосподарських підприємств України, де доцільно використовувати схему аутсорсингу є сфера надання послуг в лісовому господарстві, до яких відносяться послуги 3 лісовідновлення та лісорозведення (підготовка грунту, посів, посадка, поновлення лісових культур, догляд за ними, реконструкція малоцінних насаджень тощо), підготування лісосік та послуги на лісосіці (заготівлі деревини шляхом проведення вибіркових чи суцільних рубок), первинного оброблення та навантаження і розвантаження деревини, а також транспортування та трелювання дерев. Цей перелік послуг відповідає коду 02.40.10 Державного класифікатора продукції та послуг (DK 016:2010, 2010). Із наведеного переліку послуг у лісовому господарстві недоцільно передавати лише функції з управління лісовим господарством (планування та організація лісогосподарських робіт) та здійснення контролю за кількісними та якісними показниками виконання лісогосподарських послуг залученими підприємствами. Варто також відмітити, що така модель господарювання $є$ притаманною для більшості європейських лісогосподарських підприємств (у Європі навіть існує асоціація європейських лісових підрядників ENFE, яких ще називають лісовими контрактерами). Позитивом цієї моделі $є$ те, що при створенні конкурентного ринку лісогосподарських послуг лісгоспи отримують економію на виконанні цих послуг, внаслідок підвищення спеціалізації надавачів цих послуг, що в свою чергу підвищує якість виконуваних лісових робіт. Крім того, держлісгоспам не потрібно утримувати значний штат постійних робітників, зайнятість яких змінюється протягом року, оскільки для лісового господарства притаманною $є$ сезонність роботи.

Залучення підрядників здійснюється на основі проведення тендеру (форми розміщення замовлення на виконання робіт, послуг, поставку продукції, що передбачає вибір підрядника шляхом оцінки його пропозиціі). Основним документом, що регламентує проведення тендерних процедур є Закон України «Про публічні закупівлі» 25 грудня 2015 року № 922-XIX (Zakon Ukrayiny «Pro publichni zakupivli», 2015). 
Дія Закону України «Про публічні закупівлі» (згідно статті 2) застосовується до всіх замовників та закупівель товарів, робіт і послуг, які повністю або частково здійснюються за рахунок державних коштів, за умови, що вартість предмета закупівлі товару (товарів), послуги (послуг) дорівнює або перевищує 200 тисяч гривень (Zakon Ukrayiny «Pro publichni zakupivli», 2015).

Найбільш прийнятною процедурою закупівлі товарів, послуг і робіт, передбачених у Законі України «Про публічні закупівлі», для залучення підрядників державними лісогосподарськими підприємствами є проведення процедури відкритих торгів. Основним недоліком процедури відкритих торгів $є$ дуже великий термін ії проведення, що знижує оперативність прийняття рішень.

У Законі України «Про публічні закупівлі» закладено кілька механізмів мінімізації ризику невиконання підрядником умов договору. Так, замовник може (згідно статті 16) встановлювати для постачальника кваліфікаційні вимоги (наявності обладнання, кваліфікації робітників, фінансової спроможності та досвіду виконання аналогічних договорів) або вимагати забезпечення тендерних пропозицій і виконання договору про закупівлю. У разі неприйняття учасником пропозиції конкурсних торгів або невиконання договору про закупівлю забезпечення переходить у власність замовника (Zakon Ukrayiny «Pro publichni zakupivli», 2015).

До позитивних моментів Закону України «Про публічні закупівлі» можна віднести обов'язок замовника оприлюднювати всю інформацію про закупівлі на веб-порталі Міністерства економічного розвитку і торгівлі України та надавати їі усім зацікавленим особам. Позитивом також $€$ обов'язок додатково розміщувати оголошення про проведення процедури закупівлі (якщо очікувана вартість закупівлі перевищує суму, еквівалентну: для товарів та послуг - 133 тис. євро; для робіт - 5150 тис. євро) та про їі результати у міжнародному інформаційному виданні з питань державних закупівель Уповноваженого органу та на веб-порталі Уповноваженого органу англійською мовою (Zakon Ukrayiny «Pro publichni zakupivli», 2015). При цьому переклад назв товарів, робіт і послуг можна здійснити за допомогою Національного класифікатора Укра- 
їни «Єдиний закупівельний словник» ДК 021:2015 (CPV 2008, IDT) (DK 021:2015, 2015), який містить перелік їх кодів та назв у відповідності з європейським закупівельним словником CommonProcurementVocabulary (CPV). Норма щодо необхідності опублікування інформації про процедури закупівель у міжнародному інформаційному виданні спрямована на сприяння залучення до виконання послуг, які закуповуються за державні кошти, іноземних підприємств та організацій, які володіють передовими технологіями виробництва та методами його організації, що в кінцевому випадку сприяє перейманню позитивного зарубіжного досвіду українськими підприємствами.

Якщо ж розглядати державне регулювання закупівель товарів, послуг і робіт з позиції постійних лісокористувачів, то встановлення мінімального обсягу закупівель за державні кошти у обсязі 200 тис. грн, які повинні здійснюватись на основі процедур передбачених Законом України «Про публічні закупівлі», $є$ неефективним, оскільки обсяг лісогосподарських послуг у розрахунку на окремий об'єкт (лісову ділянку, виділ) може бути нижчим встановленого мінімуму, і тоді передбачені процедури підприємство має право не використовувати. Однак у діяльності державного підприємства перманентно закладеним є конфлікт інтересів працівників цих суб'єктів господарювання. Особливо це стосується лісової сфери, у якій $є$ можливим вилучення лісоресурсної ренти керівництвом лісгоспів. Тому з метою попередження виникнення корупційних дій доцільно було б законодавчо закріпити норму, яка передбачала 6 здійснення процедур закупівлі лісогосподарських послуг, які підприємство планує виконувати за допомогою сторонніх суб'єктів господарювання, у повному обсязі на основі процедури відкритих торгів. Це дозволить усунути конфлікт інтересів при прийнятті майнових рішень працівниками державних лісових господарств. Отже, виходячи з постулатів теорії поведінки економічних суб'єктів, згідно якої кожна особа прагне максимізувати власну вигоду, можна передбачити прагнення працівників державних лісогосподарських підприємств до вилучення ресурсної ренти. Як засіб позбавлення права приймати майнові рішення керівництва лісгоспів є здійснення закупівель товарів, послуг та робіт шляхом проведення тендерів. У цьому випадку керівник лісо- 
вого господарства не має можливості вибирати матеріально пов’язаних з ним постачальників і усуваються можливості щодо вилучення ресурсної ренти.

\section{Висновки}

Отже, можна зазначити, що у випадку втілення в життя запропонованих вище заходів очікується покращення показників ефективності господарювання більшості державних лісогосподарських підприємств України. Так, відділення деревообробки спростить систему управління цими підприємствами, знизяться адміністративні витрати, очікується підвищення рівня цін і відповідно виручки від реалізації необробленої деревини, посилення конкуренції та створення прозорого механізму ціноутворення на продукцію.

Залучення до виконання послуг з лісовідновлення та лісорозведення сторонніх суб'єктів господарювання створить умови до поглиблення поділу праці та спеціалізації лісогосподарських підрядників та підвищення рівня якості надаваних послуг, внаслідок чого лісгоспи зможуть закуповувати ці послуги за нижчими цінами та вищою якістю. Всі ці заходи сприятимуть також зміні ставлення населення до діяльності лісоводів, формуванню їх позитивного іміджу та престижності серед молоді (яка на даний час оцінюється доволі негативно, внаслідок високого рівня корупціогенності).

Вигоду отримають також і сторонні підприємства-надавачі лісогосподарських послуг та покупці необробленої деревини, які зможуть розвивати власні виробництва без встановлення корупціогенних зв'язків з керівництвом держлісгоспів і орієнтуватися на підвищення власної конкурентоспроможності шляхом впровадження інвестиційних проектів, спрямованих на створення нових продуктів, втілення в життя нових методів організації та технологій виробництва, які дозволяють знижувати собівартість продукції і завдяки цьому перемагати в конкурентній боротьбі.

Позитивом від втілення запропонованих заходів для держави $€$ спрощення та упорядкування економічних відносин у лісовій сфері, зниження рівня економічної злочинності та зростання рівня податкових надходжень до державного та місцевих бюджетів. 


\section{References}

Bendukidze, K.A. (2003). Kontseptsiya restrukturizatsii i eye voploshcheniye na predpriyatiyakh $\mathrm{OMZ}$, Sankt-Peterburg: Rossiyskiy zhurnal menedzhmenta, p. 137-144 (in Russian).

Kouz, R. (2007). Firma, rynok i pravo, Moskva: Novoye izdatel'stvo, 224 p. (in Russian).

Marchuk, Y.U. (2008). Esli chastnym predpriyatiyam nuzhna drevesina, pust' platyat, Kiyev: Biznes. № 29 (808), p. 13-14 (in Russian).

Nort, D. (1997). Instituty, institutsional'nyye izmeneniya i funktsionirovaniye ekonomiki, Moskva: Fond ekonomicheskoy knigi «Nachala», 180 p. (in Russian).

\section{Internet sources}

Derzhavnyy klasyfikator produktsiyi ta posluh DK 016-2010. Publication 21.10.2015. Retrieved from: http://www.buhgalteria.com.ua/News/d.html?id=627 (in Ukrainian) (access 4.12.2017).

Konstytutsiya Ukrayiny. Publication 2.06.2016. Retrieved from: http://zakon2.rada. gov.ua/laws/show/254\%D0\%BA/96-\%D0\%B2\%D1\%80 (in Ukrainian) (access 4.12.2017).

Natsional'nyy klasyfikator Ukrayiny "Klasyfikatsiya vydiv ekonomichnoyi diyal'nosti» DK 009:2010. Publication 29.11.2010. Retrieved from: http://zakon2.rada.gov.ua/ $\mathrm{rada} / \mathrm{show} / \mathrm{vb} 457609-10$ (in Ukrainian) (access 4.12.2017).

Natsional'nyy klasyfikator Ukrayiny «Yedynyy zakupivel'nyy slovnyk» DK 021:2015 (CPV:2002, IDT). Publication 23.12.2015. Retrieved from: http://dk21.dovidnyk. info (in Ukrainian) (access 4.12.2017).

Robochyy plan (dorozhnya karta) na 2006 rik. Derzhavnyy komitet lisovoho hospodarstva. Publication 15.03.2006. Retrieved from: http://dklg.kmu.gov.ua/forest/document/35818;/rob\%20plan.doc (in Ukrainian) (access 4.12.2017).

Rozporyadzhennya Kabinetu Ministriv Ukrayiny "Pro skhvalennya Kontseptsiyi reformuvannya ta rozvytku lisovoho hospodarstva» vid 18 kvitnya 2006 r. № 208-p. Publication 18.04.2006. Retrieved from: http://zakon2.rada.gov.ua/laws/show/208 -2006-\%D1\%80 (in Ukrainian) (access 4.12.2017).

Ukaz Prezydenta Ukrayiny «Pro Polozhennya pro Derzhavne ahentstvo lisovykh resursiv Ukrayiny» vid 13 kvitnya 2011 roku № 458/2011. Publication 13.04.2011. Retrieved from: http://zakon3.rada.gov.ua/laws/show/458/2011 (in Ukrainian) (access 4.12.2017). 
Zakon Ukrayiny «Pro pryvatyzatsiyu derzhavnoho mayna» vid 4 bereznya 1992 roku, \# 2163-12. Publication 16.02.2016. Retrieved from: http://zakon3.rada.gov.ua/ laws/show/2163-12 (in Ukrainian) (access 4.12.2017).

Zakon Ukrayiny "Pro pryvatyzatsiyu nevelykykh derzhavnykh pidpryyemstv (malu pryvatyzatsiyu)» vid 6 bereznya 1992 roku, \# 2171-12. Publication 13.05.2014. Retrieved from: http://zakon3.rada.gov.ua/laws/show/2171-12 (in Ukrainian) (access 4.12.2017).

Zakon Ukrayiny «Pro publichni zakupivli» vid 25 hrudnya 2015 roku \# 922-19. Publication 13.04.2017. Retrieved from: http://zakon2.rada.gov.ua/laws/show/922-19 (in Ukrainian) (access 4.12.2017).

Zakon Ukrayiny «Pro zasady vnutrishn'oyi i zovnishn'oyi polityky» vid 1 lypnya 2010 roku \# 2411-17. Publication 7.11.2017. Retrieved from: http://zakon5.rada.gov.ua/ laws/show/2411-17 (in Ukrainian) (access 4.12.2017). 
